\title{
A Phase I, open-label, dose-escalation study of continuous once-daily oral treatment with afatinib in patients with advanced solid tumors
}

\author{
Michael S. Gordon • David S. Mendelson • Mitchell Gross • \\ Martina Uttenreuther-Fischer • Mahmoud Ould-Kaci • \\ Yihua Zhao • Peter Stopfer • David B. Agus
}

Received: 22 October 2012 / Accepted: 7 November 2012 /Published online: 15 December 2012

(C) Springer Science+Business Media New York 2012

Summary Background This trial evaluated the safety, tolerability and maximum tolerated dose (MTD) of afatinib, a novel ErbB Family Blocker. Methods In this open-label, dose-escalation Phase I study, afatinib was administered

Trial registration NA, first patient in 16 Nov 2004

M. S. Gordon $(\bowtie) \cdot$ D. S. Mendelson

Pinnacle Oncology Hematology, 9055 E Del Camino, Suite 100,

Scottsdale, AZ 85258, USA

e-mail: mgordon@azpoh.com

D. S. Mendelson

e-mail:dmendelson@azpoh.com

M. Gross • D. B. Agus

Cedars Sinai Medical Center, Los Angeles, CA, USA

M. Gross

e-mail: mitchell.gross@usc.edu

D. B. Agus

e-mail: agus@USC.edu

M. Uttenreuther-Fischer $\cdot$ Y. Zhao $\cdot$ P. Stopfer

Boehringer Ingelheim Pharma GmbH \& Co KG,

Biberach, Germany

M. Uttenreuther-Fischer

e-mail: martina.uttenreuther-fischer@boehringer-ingelheim.com

Y. Zhao

e-mail: mary.zhao@boehringer-ingelheim.com

P. Stopfer

e-mail: peter.stopfer@boehringer-ingelheim.com

M. Ould-Kaci

Boehringer Ingelheim, Paris, France

e-mail: mahmoud.ould-kaci@boehringer-ingelheim.com

Present Address:

M. Gross • D. B. Agus

University of Southern California, Los Angeles, CA, USA continuously, orally, once-daily for 28 days to patients with advanced or metastatic solid tumors. Dose escalation was performed in a $3+3$ design, with a starting dose of $10 \mathrm{mg} /$ day (d); doses were doubled for each successive cohort until the MTD was defined. The MTD cohort was expanded to a total of 19 patients. Incidence and severity of adverse events (AEs), antitumor activity and pharmacokinetics were assessed. Results Thirty patients received at least one dose of afatinib. Twenty-nine patients were evaluable for response. Dose-limiting toxicities (DLTs) consisting of Grade 3 diarrhea were observed in two out of three patients treated at $60 \mathrm{mg} / \mathrm{d}$. The MTD was determined at $40 \mathrm{mg} / \mathrm{d}$. The most frequent treatment-related AEs were diarrhea and mucosal inflammation reported in $76.7 \%$ and $43.3 \%$ of patients respectively. Five patients had stable disease with a median progressionfree survival of 111 days. No objective responses occurred. Pharmacokinetic data showed no deviation from doseproportionality and steady-state was reached on Day 8 at the latest. Conclusions Afatinib was well tolerated with manageable side effects when administered once-daily, continuously at a dose of $40 \mathrm{mg}$.

Keywords Afatinib · Phase I - ErbB Family Blocker · Dose escalation · Irreversible tyrosine kinase inhibitor

\section{Background}

The ErbB Family of receptor tyrosine kinases bind various extracellular growth factors and play a crucial role in regulating cell growth and proliferation [1,2]. The four members of the ErbB Receptor Family are the epidermal growth factor receptor (EGFR, ErbB1), HER2 (ErbB2), HER3 (ErbB3) and HER4 (ErbB4) and comprise an extracellular 
ligand-binding domain (except for HER2), a single membrane-spanning domain and, on the cytoplasmic side of the cell membrane, a tyrosine kinase active site (except for HER3) [3]. Binding of extracellular growth factor ligands to the ErbB Receptor Family causes a structural change in the receptor which facilitates dimerization of the receptors, which can form homo- or heterodimers. This stimulates their tyrosine kinase activity, initiating intracellular signaling cascades $[2,4]$. HER2 has no associated ligand, but functions as a coreceptor with the other members of the ErbB Family - it is the preferred dimerization partner for the other receptors [3, 4].

Dysregulated signaling via members of the ErbB Receptor Family plays a role in different tumor types [3, 5-7]. As a result of this observation, a number of compounds have been developed which inhibit signaling via the ErbB Receptor Family tyrosine kinases. The currently available smallmolecule tyrosine kinase inhibitors, gefitinib and erlotinib, target EGFR and have improved clinical outcomes in nonsmall cell lung cancer (NSCLC) [8-12]. Similarly, the humanized monoclonal antibody, trastuzumab, directed against the extracellular domain of the HER2 receptor, is indicated for the treatment of HER2-positive breast cancer in the adjuvant and metastatic setting, as well as the small molecule dual EGFR and HER2 tyrosine kinase inhibitor lapatinib in combination with capecitabine, which has clinical efficacy in metastatic breast cancer [13, 14]. The success of these agents validates the ErbB Receptor Family as a target for cancer therapy.

Further developments in understanding how the currently available reversible tyrosine kinase inhibitors mediated their effects on the ErbB Receptor Family led to the design of afatinib (BIBW 2992), an oral irreversible ErbB Family Blocker with half-maximal inhibitory concentration (IC50) values of $0.5 \mathrm{nM}, 14 \mathrm{nM}, 1 \mathrm{nM}$ and $10 \mathrm{nM}$ for EGFR, HER2, HER4, and EGFR L858R/T790M, respectively [15, 16]. Afatinib irreversibly blocks ErbB Receptor Family tyrosine kinase activity and, in doing so, is thought to inhibit all cancer-relevant ErbB Family dimers. In preclinical models, this prevents tumor growth and can also initiate tumor regression [16]. So far, afatinib has demonstrated substantial, sustained activity in vitro and broad spectrum activity in vivo xenograft models [16-18].

Several Phase I studies have investigated the safety and antitumor activity of afatinib monotherapy when administered either as a 2-week on/off schedule [15], a 3-week on/1-week off schedule $[19,20]$ or as continuous dosing [21]. The recommended Phase II dose (RP2D) of afatinib was reported as $70 \mathrm{mg}$ once-daily in the 2-week on/off study and shown to be well tolerated. For the 3-week on/1-week off schedule study, the maximum tolerated dose (MTD) was established at $55 \mathrm{mg} / \mathrm{d}$; however, due to excess dose-limiting toxicities (DLTs) in the MTD expansion cohort it was not considered as a RP2D. Continuous afatinib dosing was explored in two separate Phase I studies. One of these studies has already been reported [21] and established a RP2D at $50 \mathrm{mg}$ once-daily continuous. Results from the other study investigating a continuous schedule are reported here.

The primary objective of this study was to determine the safety and tolerability, and to establish the MTD of oral, once-daily afatinib when administered continuously in 28daycycles. Secondary objectives were to assess the antitumor activity of afatinib, as well as its pharmacokinetic profile at steady state.

\section{Methods}

Study design

This was a Phase I, two-center, open-label study designed to establish the MTD and assess the overall safety and antitumor activity of afatinib in patients with advanced solid tumors. Patients received a single daily oral dose of afatinib for 28 days continuously. If treatment was tolerated, patients were allowed to receive repeated 28-day treatment cycles until the occurrence of progressive disease or toxicity. The afatinib starting dose for the first cohort was $10 \mathrm{mg} / \mathrm{d}$, and the dose was doubled for each successive cohort until one or more patients experienced a DLT. Thereafter, dose escalation was to be of no more than $50 \%$ increments.

The trial was conducted in a $3+3$ design. Three patients were treated at each dose level. If one of them experienced a DLT, three additional patients were treated at that dose level. The MTD was the highest dose at which no more than one of six patients experienced a DLT. If two or more patients experienced a DLT, a total of six patients were treated at one dose tier below. Once the MTD was established, subject enrolment at the MTD was expanded to include a minimum of 18 patients to better characterize the safety profile, antitumor activity and the pharmacokinetic properties. Patients who experienced a DLT stopped study medication but could restart at a lower dose level if they recovered to Grade $\leq 1$ adverse event (AE) within 2 weeks.

The following drug-related AEs (National Cancer Institute Common Terminology Criteria for Adverse Events; NCI CTCAE version 3.0) [22] qualified as DLTs: Grade 4 hematologic toxicity, Grade 3 or 4 non-hematologic toxicity (except untreated nausea, untreated vomiting, or untreated diarrhea); Grade 2 or higher worsening of cardiac left ventricular function; Grade 2 or higher worsening of renal function as measured by serum creatinine, newly developed proteinuria, or newly developed decrease in glomerular filtration rate; Grade $\geq 3$ diarrhea despite loperamide or other anti-diarrheal medication; persistent Grade $\geq 2$ diarrhea for 7 or more days despite supportive care; Grade $\geq 3$ nausea and/or vomiting despite antiemetic treatment; persistent Grade $\geq 2$ nausea and/or vomiting for 7 or more days despite supportive care. 
Patients underwent response assessment as defined in the Response Evaluation Criteria In Solid Tumors (RECIST) version 1.0 following completion of two 28-daycycles of therapy. Patients with stable disease or objective response who were tolerating study drug were eligible for continued therapy with repeat response assessments every other cycle.

\section{Study population}

Male or female patients with a pathologically confirmed solid tumor, historically known to express EGFR and/or HER2, for whom no proven therapy existed or who were not amenable to established treatments, were eligible. Other eligibility criteria included: informed consent; age $\geq 18$ years; Eastern Cooperative Oncology Group (EGOG) performance status of 0-2; life expectancy of at least 3 months; recovery from any prior surgery and any AEs related to previous therapy, and no prior treatment with an EGFR- or HER2inhibiting drug within 4 weeks ( 8 weeks for trastuzumab) before the start of study medication.

An additional 12 patients recruited at the MTD were also required to have measurable disease according to RECIST version 1.0 [23] or evaluable disease using recognized tumor markers, such as prostate-specific antigen for prostate cancer or cancer antigen 125 for ovarian cancer.

\section{Concomitant medications}

Concomitant medications were given as clinically required. Recommendations for treatment of diarrhea, nausea, vomiting and rash were provided in the protocol. Additional chemo-, immuno-, hormone- or radiotherapy was not permitted, with the exception of ongoing hormone treatment for prostate cancer, bisphosphonates, or palliative radiotherapy.

\section{Outcome measures}

Safety was assessed by monitoring the incidence and severity of AEs, which were graded according to the NCI CTCAE criteria version 3.0. Antitumor activity was assessed by tumor measurements according to RECIST and performed at 8-week intervals.

\section{Pharmacokinetic analysis}

Plasma concentrations of afatinib were determined at distinct time points on Day 1: pre-dose, $3 \mathrm{~h}$ and $24 \mathrm{~h}$ after the first drug administration. Pharmacokinetic (PK) parameters of afatinib were determined on Days 27-28 (steady state) of continuous treatment at the following timepoints: before drug administration and 1, 2, 3, 4, 5, 9 and $24 \mathrm{~h}$ after drug administration. Trough levels were determined on Days 8 , 15 and 22 in the first treatment cycle and on Days 15 and 28 during repeated treatment periods up to the sixth cycle of therapy.

Noncompartmental analysis was conducted using WinNonlin $^{\circledR}$ (version 4.1, Pharsight, Mountainview, CA). Standard noncompartmental methods were used to calculate the area under the plasma concentration-time curve over the time interval from 0 to $24 \mathrm{~h}$ at steady state $\left(\mathrm{AUC}_{0-24, \mathrm{ss}}\right)$, maximum measured concentration of the analyte in plasma at steady state $\left(\mathrm{C}_{\max , \mathrm{ss}}\right)$, apparent clearance of the analyte in plasma following extravascular administration $\left(\mathrm{CL} / \mathrm{F}_{\mathrm{ss}}\right)$, apparent volume of distribution during the terminal phase following an extravascular dose $\left(\mathrm{V}_{\mathrm{z}} / \mathrm{F}_{\mathrm{ss}}\right)$ and terminal halflife of the analyte in plasma at steady state $\left(\mathrm{t}_{1 / 2, \mathrm{ss}}\right)$. Time from dosing to the maximum concentration of the analyte in plasma at steady state $\left(\mathrm{t}_{\max , \mathrm{ss}}\right)$ was reported as a median value.

\section{Results}

Patient demographics and disposition

A total of 30 patients received at least one dose of afatinib and were included in the safety analysis. The baseline demographic characteristics of these patients are provided in Table 1. Patients had different cancer types (the most common being ovarian and NSCLC) and were heavily pretreated $(96.7 \%$ had $\geq 3$ prior anticancer therapies). Patient disposition and exposure are listed in Table 2. The MTD cohort included six patients to establish the MTD and an additional 13 patient expansion cohort instead of the planned 12 , as two patients were entered very close together in time. This gave a total of 19 patients treated at MTD.

\section{Assessment of DLT and MTD}

In total, three patients developed DLT during the first 28day treatment cycle in the dose escalation phase, two out of three patients in the $60 \mathrm{mg}$ cohort and one patient in the $40 \mathrm{mg}$ cohort. Of the two DLTs that occurred in the $60 \mathrm{mg}$ cohort, one patient was 80 years old, with prostate cancer, and the second patient was 77 years old, with endometrial cancer. In both cases, Grade 3 diarrhea occurred despite an optimal anti-diarrheal treatment. One of these patients (an 80 year-old with prostate cancer) continued on treatment after dose reduction to $40 \mathrm{mg} / \mathrm{d}$. With two of three DLTs observed in the afatinib $60 \mathrm{mg}$ cohort and no DLT observed with the afatinib $40 \mathrm{mg}$ dose in the initial cohort of three patients, the $40 \mathrm{mg}$ dose was further assessed in six patients, and with one DLT (Grade 3 diarrhea occurred in a 66 yearold patient with ovarian cancer), it was established as the MTD. The cohort was then expanded by a further 13 patients without additional DLTs occurring. As no intermediate dose between $40 \mathrm{mg}$ and $60 \mathrm{mg}$ afatinib was planned 
Table 1 Baseline demographic and disease characteristics

\begin{tabular}{|c|c|}
\hline & Total \\
\hline Number of patients treated, n (\%) & $30(100)$ \\
\hline \multicolumn{2}{|l|}{ Age (years) } \\
\hline Median (range) & $60.0(35-80)$ \\
\hline \multicolumn{2}{|l|}{ Gender, n (\%) } \\
\hline Male & $18(60)$ \\
\hline Female & $12(40)$ \\
\hline \multicolumn{2}{|l|}{ Race, n (\%) } \\
\hline White & $25(83.3)$ \\
\hline Black & $4(13.3)$ \\
\hline Asian & $1(3.3)$ \\
\hline \multicolumn{2}{|l|}{ Smoking status, n (\%) } \\
\hline Never-smoker & $10(33.3)$ \\
\hline Ex-smoker & $19(63.3)$ \\
\hline Smoker & $1(3.3)$ \\
\hline \multicolumn{2}{|l|}{ ECOG PS at screening, $\mathrm{n}(\%)$} \\
\hline 0 & $13(43.3)$ \\
\hline 1 & $12(40.0)$ \\
\hline 2 & $5(16.7)$ \\
\hline \multicolumn{2}{|l|}{ Cancer type, n (\%) } \\
\hline Ovarian & $6(20.0)$ \\
\hline NSCLC & $4(13.3)$ \\
\hline Prostate & $3(10.0)$ \\
\hline Renal & $3(10.0)$ \\
\hline Breast & $3(10.0)$ \\
\hline Colorectal & $2(6.7)$ \\
\hline Pancreatic & $2(6.7)$ \\
\hline Other & $7(23.3)$ \\
\hline \multicolumn{2}{|l|}{ Number of prior therapies, $\mathrm{n}(\%)$} \\
\hline 2 & $1(3.3)$ \\
\hline$\geq 3$ & $29(96.7)$ \\
\hline \multicolumn{2}{|c|}{ Number of prior chemotherapy regimens, n (\%) } \\
\hline 0 & $1(3.3)$ \\
\hline $1-2$ & $4-9(30.0)$ \\
\hline$\geq 3$ & $20(66.7)$ \\
\hline Prior radiotherapy, $\mathrm{n}(\%)$ & $18(60.0)$ \\
\hline
\end{tabular}

ECOG PS, Eastern Cooperative Oncology Group performance status; NSCLC, non-small cell lung cancer

in the study, the MTD and RP2D for afatinib was defined at $40 \mathrm{mg} /$ day when administered once-daily in a 28-day continuous-dosing treatment schedule.

Safety and tolerability assessments

All 30 patients included in the safety analysis experienced at least one AE - 29 had AEs considered by the investigators to be related to study medication. The most frequently reported treatment-related AEs are summarized by dose group and treatment cycle (cycle 1 versus cycle $\geq 2$ ) and CTCAE Grade in Table 3. Across all dose groups and treatment courses, diarrhea was the most commonly reported treatment-related $\operatorname{AE}(76.7 \%)$, followed by mucosal inflammation (43.3\%), rash and nausea (both $36.7 \%$ ), fatigue and dermatitis acneiform (both $33.3 \%$ ). Diarrhea occurred across all dose ranges, but CTCAE Grade 3 events occurred only in the $40 \mathrm{mg} / \mathrm{d}$ and $60 \mathrm{mg} / \mathrm{d}$ groups. The onset of diarrhea typically occurred during the first treatment course in $70 \%$ of patients. However, $76.7 \%$ of the patients reported diarrhea during all courses.

Six deaths were reported; one occurred during the treatment period and five other deaths were reported in the posttreatment period. None were considered to be related to the study medication.

No relevant changes in laboratory evaluations, i.e. those determined to be CTCAE Grade $\geq 2$, were related to study medication. No cardiac events were reported throughout the treatment period.

Antitumor activity

Twenty-nine out of 30 patients who had evaluable disease as per RECIST were included in the tumor response analysis. No objective responses were observed during the course of this study. Three patients remained on treatment for more than 16 weeks: one in the $20 \mathrm{mg} / \mathrm{d}$ group and two in the $40 \mathrm{mg} / \mathrm{d}$ group. Two of these had stable disease beyond six treatment courses (24 weeks) - one ovarian cancer patient in the $20 \mathrm{mg}$ group (204 days) and one patient with thymic carcinoma in the $40 \mathrm{mg}$ group (280 days). In the $40 \mathrm{mg}$ dose cohort, five patients (three with ovarian cancer, one with thyroid cancer and one with prostate cancer) experienced stable disease with a median progression-free survival of 111 days (range: 49-204 days).

\section{Pharmacokinetics}

Individual and geometric mean (gMean) drug plasma concentration-time profiles of afatinib (40 $\mathrm{mg}$ dose group) during Treatment Period 1 are shown in Fig. 1. Steady-state was reached on Day 8 of Treatment Period 1 at the latest. Moderate-to-high inter-individual variability of the plasma concentrations of the patients in the $40 \mathrm{mg}$ dose group was detected.

Across all dose groups, median $t_{\max }$ values at steady state ranged from 3 to $5 \mathrm{~h}$ after oral administration of afatinib. In general, at steady-state, gMean $\mathrm{C}_{\max }$ values and total exposure increased with increasing doses of afatinib (Table 4) and there was no obvious deviation from dose-proportionality. It should be noted that the gMean pharmacokinetic parameters of the $20 \mathrm{mg}$ dose group $(n=3)$ were mainly influenced by one single patient, who displayed much higher afatinib plasma concentrations compared with the rest of the $20 \mathrm{mg}$ dose group. As a result, values of the $20 \mathrm{mg}$ dose group were 
Table 2 Patient disposition

${ }^{\mathrm{a} O n e}$ patient continued on afatinib treatment after dose reduction to $40 \mathrm{mg} /$ day

DLT, dose-limiting toxicity; AE, adverse event; Other, worsening of disease under study, lost to follow-up, non-compliance and other

\begin{tabular}{lllccr}
\hline Afatinib dose (mg/day) & 10 & 20 & 40 & 60 & Total \\
\hline $\begin{array}{l}\text { Patients treated (n) } \\
\begin{array}{l}\text { Patients with DLT events during } \\
\text { the initial 28-day treatment period (n) }\end{array}\end{array}$ & 5 & 3 & 19 & 3 & 30 \\
Patients discontinued owing to (n, \%): & 0 & 0 & 1 & $2^{\mathrm{a}}$ & 3 \\
DLT & 0 & 0 & $1(5.3)$ & $1(33.3)$ & $2(6.7)$ \\
Other AEs & 0 & 0 & $2(10.5)$ & $1(33.3)$ & $3(10.0)$ \\
Disease progression & $4(80)$ & $3(100)$ & $14(73.7)$ & $1(33.3)$ & $22(73.3)$ \\
Other & $1(20)$ & 0 & $2(10.5)$ & 0 & $3(10.0)$ \\
\hline
\end{tabular}

therefore in a similar range to the pharmacokinetic parameters of the $40 \mathrm{mg}$ dose group. The gMean terminal half-life following oral dosing ranged from 34 to $48 \mathrm{~h}$; the overall gMean was $37.4 \mathrm{~h}$ (data not shown). Total body clearance was determined with gMean values between $567 \mathrm{~mL} / \mathrm{min}$ and $2,980 \mathrm{~mL} / \mathrm{min}$ and an overall $\mathrm{gMean}$ of $1,330 \mathrm{~mL} / \mathrm{min}$ across all groups (data not shown). Afatinib exhibited a high apparent volume of distribution during the terminal phase, with gMean values between 1,990 and 16,100 liters (overall gMean: 3,630 liters - data not shown). However, values obtained for total body clearance and volume of distribution should be treated with caution, as the absolute bioavailability of afatinib in humans is unknown.

\section{Discussion}

A number of small-molecule tyrosine kinase inhibitors have been developed, which target the receptors of the ErbB
Family, including gefitinib, erlotinib and lapatinib. These compounds have shown efficacy in the treatment of various solid tumors, including NSCLC [8-12] and metastatic breast cancer $[13,14]$. Despite the improvements achieved in patient outcomes with reversible inhibitors of EGFR or EGFR and HER2, primary and acquired resistance to these agents remains a clinical challenge. This is exemplified by the emergence of resistance mechanisms such as the T790M EGFR mutation in NSCLC [24]. It is likely that patients will benefit from treatment with an irreversible ErbB Family Blocker, such as afatinib that showed activity against EGFR-mutated NSCLC as well as in trastuzumab resistant HER2-positive metastatic breast cancer [25].

This Phase I dose-escalation study was performed to determine the safety and tolerability, and to establish the MTD for continuous administration of afatinib, an ErbB Family Blocker. Results from this trial show that afatinib administered continuously for 28 days at the MTD of $40 \mathrm{mg} / \mathrm{d}$ is well tolerated with a manageable safety profile.

Table 3 Selected treatment-related adverse events by treatment dose, highest CTCAE Grade and preferred term

\begin{tabular}{|c|c|c|c|c|c|c|c|c|c|c|c|c|c|c|c|c|c|c|c|c|c|c|c|c|}
\hline \multirow{3}{*}{$\begin{array}{l}\text { Afatinib dose (mg/day) } \\
\text { Grade }^{a} \\
\text { Course }^{b}\end{array}$} & \multicolumn{4}{|c|}{10} & \multicolumn{8}{|c|}{20} & \multicolumn{6}{|l|}{40} & \multicolumn{6}{|c|}{60} \\
\hline & \multicolumn{2}{|l|}{1} & \multicolumn{2}{|l|}{2} & \multicolumn{2}{|l|}{1} & \multicolumn{2}{|l|}{2} & \multicolumn{2}{|l|}{3} & \multicolumn{2}{|l|}{4} & \multicolumn{2}{|l|}{1} & \multicolumn{2}{|l|}{2} & \multicolumn{2}{|l|}{3} & \multicolumn{2}{|l|}{1} & \multicolumn{2}{|l|}{2} & \multicolumn{2}{|l|}{3} \\
\hline & 1 & $\geq 2$ & 1 & $\geq 2$ & 1 & $\geq 2$ & 1 & $\geq 2$ & 1 & $\geq 2$ & 1 & $\geq 2$ & 1 & $\geq 2$ & 1 & $\geq 2$ & 1 & $\geq 2$ & 1 & $\geq 2$ & 1 & $\geq 2$ & 1 & $\geq 2$ \\
\hline Decreased appetite & 0 & 0 & 0 & 0 & 0 & 0 & 0 & 0 & 0 & 1 & 0 & 0 & 3 & 0 & 0 & 1 & 1 & 0 & 2 & 0 & 0 & 0 & 0 & 0 \\
\hline Diarrhea & 0 & 0 & 2 & 0 & 1 & 0 & 1 & 1 & 0 & 0 & 0 & 0 & 9 & 1 & 3 & 0 & 2 & 0 & 0 & 0 & 1 & 0 & 2 & 0 \\
\hline Nausea & 1 & 0 & 1 & 0 & 0 & 0 & 1 & 0 & 0 & 0 & 1 & 0 & 2 & 2 & 1 & 0 & 0 & 0 & 1 & 0 & 0 & 1 & 0 & 0 \\
\hline Stomatitis & 0 & 0 & 0 & 0 & 0 & 0 & 1 & 0 & 0 & 0 & 0 & 0 & 3 & 1 & 1 & 0 & 0 & 0 & 1 & 0 & 0 & 0 & 0 & 0 \\
\hline Fatigue & 1 & 0 & 1 & 0 & 0 & 0 & 1 & 0 & 0 & 0 & 0 & 0 & 4 & 0 & 1 & 0 & 1 & 0 & 0 & 0 & 0 & 0 & 0 & 1 \\
\hline Rash & 0 & 0 & 0 & 0 & 0 & 1 & 0 & 0 & 0 & 0 & 0 & 0 & 4 & 2 & 1 & 0 & 0 & 0 & 1 & 0 & 2 & 0 & 0 & 0 \\
\hline Dry skin & 0 & 0 & 0 & 0 & 1 & 0 & 0 & 0 & 0 & 0 & 0 & 0 & 2 & 0 & 0 & 0 & 0 & 0 & 0 & 0 & 0 & 0 & 0 & 0 \\
\hline Dermatitis acneiform & 0 & 0 & 0 & 0 & 0 & 0 & 0 & 0 & 0 & 0 & 0 & 0 & 6 & 0 & 3 & 0 & 0 & 0 & 1 & 0 & 0 & 0 & 0 & 0 \\
\hline Rash erythematous & 0 & 0 & 0 & 0 & 0 & 0 & 1 & 0 & 0 & 0 & 0 & 0 & 2 & 0 & 0 & 0 & 0 & 0 & 0 & 0 & 0 & 0 & 0 & 0 \\
\hline Mucosal inflammation & 0 & 0 & 0 & 0 & 0 & 0 & 0 & 1 & 0 & 0 & 0 & 0 & 7 & 1 & 2 & 0 & 0 & 0 & 0 & 0 & 2 & 0 & 0 & 0 \\
\hline Epistaxis & 0 & 0 & 0 & 0 & 0 & 0 & 0 & 0 & 0 & 0 & 0 & 0 & 2 & 1 & 0 & 0 & 0 & 0 & 2 & 0 & 0 & 0 & 0 & 0 \\
\hline
\end{tabular}

${ }^{\mathrm{a}}$ Worst CTCAE Grade; ${ }^{\mathrm{b}}$ course in which AE started; cycle length: 28 days; no treatment-related Grade 3 AEs were observed in the 10 mg dose cohort

CTCAE, Common Terminology Criteria for Adverse Events; AE, adverse event 


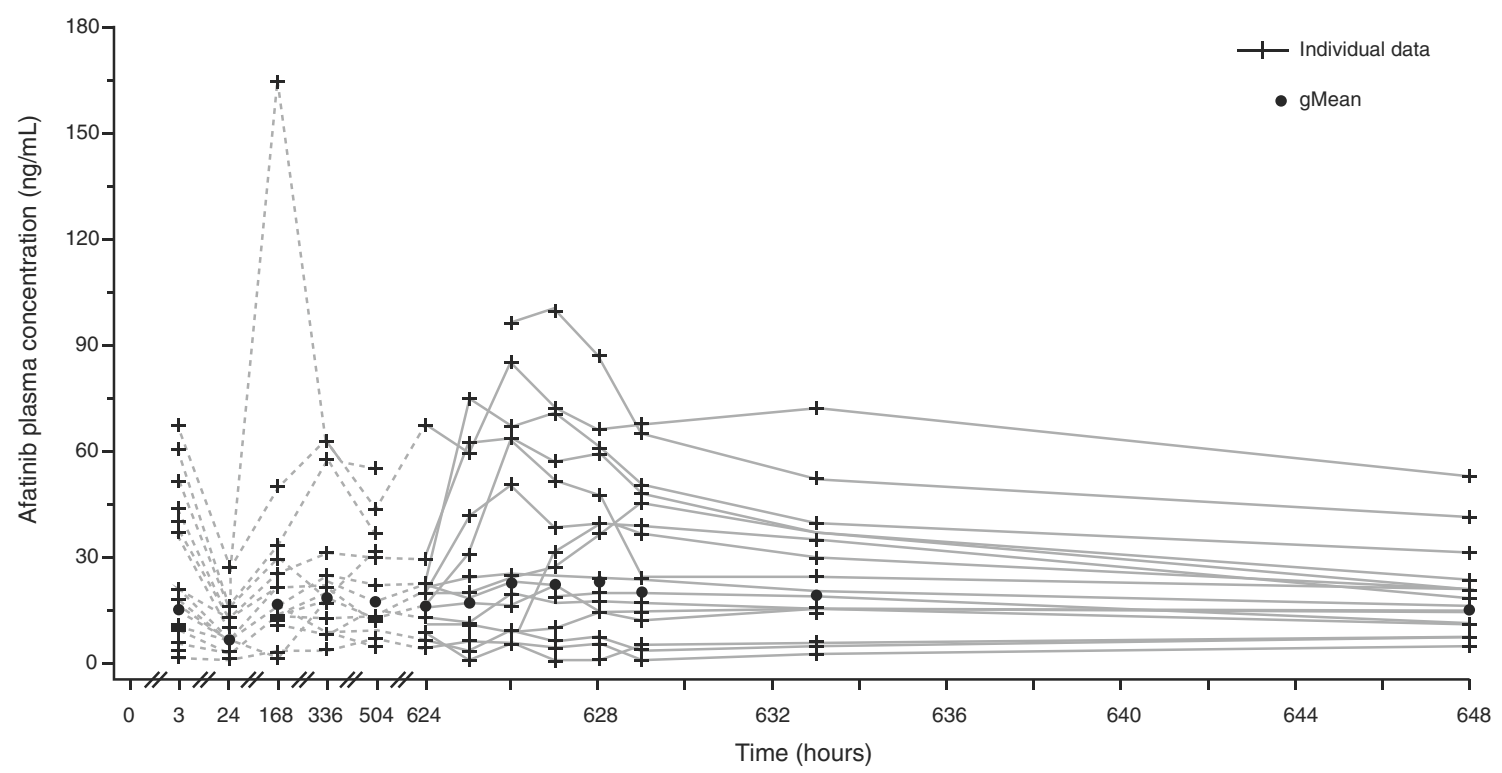

Fig. 1 Individual and gMean drug plasma concentration-time profiles of afatinib after oral administration of $40 \mathrm{mg} / \mathrm{day}$ for $27 \mathrm{days}(n=17)$. gMean, geometric mean

Dose escalation to a dose between $40 \mathrm{mg} / \mathrm{d}$ and $60 \mathrm{mg} / \mathrm{d}$, which clearly was above the MTD within this trial was not foreseen. Afatinib displayed good pharmacologic properties and pharmacokinetic results are in line with other data from Phase I studies of continuous or intermittent dosing of afatinib $[15,21,26]$. All pharmacokinetic parameters displayed moderate-to-high variability within the expected range for orally administered EGFR tyrosine kinase inhibitors $[27,28]$.

In general, the AEs that were associated with afatinib in this study and the overall safety profile of afatinib are consistent with those observed with EGFR inhibitors [29-32]. Only three patients experienced a DLT consisting of Grade 3 diarrhea (two at $60 \mathrm{mg}$, one at $40 \mathrm{mg}$ ). Gastrointestinal and skin-related AEs were reported most frequently, and usually occurred within the first 2 weeks of treatment. These AEs were manageable with dose reduction and appropriate supportive care allowing prolonged administration of afatinib as with the currently available EGFR inhibitors erlotinib and gefitinib [31, 33, 34].

Although, no objective response was observed in this trial, several heavily pre-treated patients experienced stable

Table 4 Geometric mean (and gCV\%) pharmacokinetic parameters of afatinib on Days 27-28 (steady state) after multiple oral administration of afatinib once-daily

Day 27

\begin{tabular}{|c|c|c|c|c|c|c|c|c|c|}
\hline \multicolumn{2}{|c|}{ Afatinib dose q.d. (No. of patients) } & \multicolumn{2}{|c|}{$10 \mathrm{mg}(n=3)$} & \multicolumn{2}{|c|}{$20 \mathrm{mg}(n=3)$} & \multicolumn{2}{|c|}{$40 \mathrm{mg}(n=17)$} & \multicolumn{2}{|c|}{$60 \mathrm{mg}(n=1)^{\|}$} \\
\hline & & gMean & $\mathrm{gCV}[\%]$ & gMean & $\mathrm{gCV}[\%]$ & gMean & $\mathrm{gCV}[\%]$ & gMean & $\mathrm{gCV}[\%]$ \\
\hline $\mathrm{C}_{\mathrm{max}, \mathrm{ss}}$ & {$[\mathrm{ng} / \mathrm{mL}]$} & 3.18 & 63.7 & 24.6 & 158 & 29.0 & 105 & 86.7 & - \\
\hline $\mathrm{C}_{\mathrm{pre}, \mathrm{ss}}$ & {$[\mathrm{ng} / \mathrm{mL}]$} & $2.64^{\mathrm{b}}$ & 54.4 & 12.5 & 243 & $16.1^{\mathrm{c}}$ & 66.9 & 52.3 & - \\
\hline$t_{\max , s s}{ }^{a}$ & {$[\mathrm{~h}]$} & 3.00 & $1.00-3.95$ & 5.00 & $4.98-5.08$ & 2.95 & $1.22-23.8$ & 2.98 & - \\
\hline $\mathrm{AUC}_{0-24, \mathrm{ss}}$ & {$[\mathrm{ng} \cdot \mathrm{h} / \mathrm{mL}]$} & 55.9 & 54.2 & 442 & 173 & $498^{\mathrm{c}}$ & 90.3 & 1760 & - \\
\hline$t_{1 / 2, \mathrm{ss}}$ & {$[\mathrm{h}]$} & $47.0^{\mathrm{b}}$ & 0.0356 & 48.4 & 88.9 & $34.0^{\mathrm{d}}$ & 64.6 & 40.5 & - \\
\hline $\mathrm{V}_{\mathrm{z}} / \mathrm{F}_{\text {,ss }}$ & {$[\mathrm{L}]$} & $16100^{\mathrm{b}}$ & 19.4 & 3160 & 273 & $3150^{\mathrm{d}}$ & 106 & 1990 & - \\
\hline $\mathrm{CL} / \mathrm{F}_{\mathrm{ss}}$ & {$[\mathrm{mL} / \mathrm{min}]$} & 2980 & 54.2 & 755 & 173 & $1340^{\mathrm{c}}$ & 90.3 & 567 & - \\
\hline
\end{tabular}

${ }^{\mathrm{a}}$ Median and range; ${ }^{\mathrm{b}} N=2 ;{ }^{\mathrm{c}} N=16 ;{ }^{\mathrm{d}} N=14 ;{ }^{\prime \prime}$ No descriptive statistics, only individual values from one patient

$\mathrm{AUC}_{0-24, \mathrm{ss}}$, area under the plasma concentration versus time curve from 0 to $24 \mathrm{~h}$ at steady state; $\mathrm{C}_{\mathrm{max}, \mathrm{ss}}$, peak plasma concentration at steady state; $\mathrm{C}_{\mathrm{pre}, \mathrm{ss}}$, pre-dose plasma concentrations at steady state; $\mathrm{CL} / \mathrm{F}_{\mathrm{ss}}$, apparent clearance of the analyte in plasma following extravascular administration at steady state; $\mathrm{gCV}[\%]$, geometric coefficient of variation; gMean, geometric mean; $\mathrm{t}_{1 / 2, \mathrm{ss}}$, terminal half-life at steady state; $\mathrm{t}_{\text {max,ss }}$, time to peak plasma concentration at steady state; $\mathrm{V}_{\mathrm{z}} / \mathrm{F}_{\text {ss }}$, apparent volume of distribution of the analyte in plasma following extravascular administration at steady state 
disease. It is of note that patients were not preselected based on the overexpression of EGFR or HER2.

Initial data from other Phase I dose-escalation studies in patients with advanced solid tumors showed that afatinib could be safely administered at a dose of $70 \mathrm{mg} / \mathrm{d}$ in a 2-week on/2-week off schedule [35]. Afatinib was administered with tolerable side effects at $40 \mathrm{mg} / \mathrm{d}$ in a 3-week on/1-week off schedule [36]. Results from this trial indicate that a dose of $60 \mathrm{mg} / \mathrm{d}$ is too high for a continuous dosing regimen, and that a dose of $40 \mathrm{mg} / \mathrm{d}$ can be safely administered, while data from another Phase I trial have established a RP2D at $50 \mathrm{mg} / \mathrm{d}$ [21]. This dose was subsequently assessed in Phase II and III trials and its efficacy and tolerability was confirmed in a variety of tumor types [37, 38].

In conclusion, in this trial we confirmed the good tolerability with manageable safety profile of afatinib when administered orally, at a dose of $40 \mathrm{mg}$ once-daily continuously.

Acknowledgements This study was supported by Boehringer Ingelheim. Editorial support for the preparation of this manuscript was provided by Jamie Singer of Ogilvy Healthworld Medical Education; funding was provided by Boehringer Ingelheim.

Author financial disclosures No financial disclosures related to this manuscript reported.

Ethical standards This study was carried out according to the Declaration of Helsinki and the Good Clinical Practice (GCP) and International Conference on Harmonization (ICH) guidelines, and was approved by the local Institutional Review Boards of the participating institutions. The study was conducted between November 2004 and September 2006.

\section{References}

1. Ciardiello F, Tortora G (2008) EGFR antagonists in cancer treatment. N Engl J Med 358(11):1160-1174. doi:10.1056/NEJ Mra0707704

2. Yarden Y, Sliwkowski MX (2001) Untangling the ErbB signalling network. Nat Rev Mol Cell Biol 2(2):127-137. doi:10.1038/ 35052073

3. Normanno N, Bianco C, Strizzi L, Mancino M, Maiello MR, De Luca A, Caponigro F, Salomon DS (2005) The ErbB receptors and their ligands in cancer: an overview. Curr Drug Targets 6(3):243-257

4. Holbro T, Beerli RR, Maurer F, Koziczak M, Barbas CF 3rd, Hynes NE (2003) The ErbB2/ErbB3 heterodimer functions as an oncogenic unit: ErbB2 requires ErbB3 to drive breast tumor cell proliferation. Proc Natl Acad Sci U S A 100(15):8933-8938. doi:10.1073/pnas. 1537685100

5. Arteaga CL (2002) Epidermal growth factor receptor dependence in human tumors: more than just expression? Oncologist 7(Suppl 4):31-39

6. Iivanainen E, Elenius K (2010) ErbB targeted drugs and angiogenesis. Curr Vasc Pharmacol 8(3):421-431

7. Baselga J (2002) Why the epidermal growth factor receptor? The rationale for cancer therapy. Oncologist 7(Suppl 4):2-8

8. Shepherd FA, Rodrigues Pereira J, Ciuleanu T, Tan EH, Hirsh V, Thongprasert S, Campos D, Maoleekoonpiroj S, Smylie M, Martins
R, van Kooten M, Dediu M, Findlay B, Tu D, Johnston D, Bezjak A, Clark G, Santabarbara P, Seymour L (2005) Erlotinib in previously treated non-small-cell lung cancer. N Engl J Med 353(2):123-132. doi:10.1056/NEJMoa050753

9. Mok TS, Wu YL, Thongprasert S, Yang CH, Chu DT, Saijo N, Sunpaweravong P, Han B, Margono B, Ichinose Y, Nishiwaki Y, Ohe Y, Yang JJ, Chewaskulyong B, Jiang H, Duffield EL, Watkins CL, Armour AA, Fukuoka M (2009) Gefitinib or carboplatinpaclitaxel in pulmonary adenocarcinoma. N Engl J Med 361 (10):947-957. doi:10.1056/NEJMoa0810699

10. Maemondo M, Inoue A, Kobayashi K, Sugawara S, Oizumi S, Isobe H, Gemma A, Harada M, Yoshizawa H, Kinoshita I, Fujita Y, Okinaga S, Hirano H, Yoshimori K, Harada T, Ogura T, Ando M, Miyazawa H, Tanaka T, Saijo Y, Hagiwara K, Morita S, Nukiwa T (2010) Gefitinib or Chemotherapy for Non-Small- Cell Lung Cancer with Mutated EGFR. N Engl J Med 362:2380-2388

11. Rosell R, Moran T, Queralt C, Porta R, Cardenal F, Camps C, Majem M, Lopez-Vivanco G, Isla D, Provencio M, Insa A, Massuti B, Gonzalez-Larriba JL, Paz-Ares L, Bover I, GarciaCampelo R, Moreno MA, Catot S, Rolfo C, Reguart N, Palmero R, Sanchez JM, Bastus R, Mayo C, Bertran-Alamillo J, Molina MA, Sanchez JJ, Taron M (2009) Screening for epidermal growth factor receptor mutations in lung cancer. N Engl J Med 361(10):958-967. doi:10.1056/NEJMoa0904554

12. Mitsudomi T, Morita S, Yatabe Y, Negoro S, Okamoto I, Tsurutani J, Seto T, Satouchi M, Tada H, Hirashima T, Asami K, Katakami N, Takada M, Yoshioka H, Shibata K, Kudoh S, Shimizu E, Saito H, Toyooka S, Nakagawa K, Fukuoka M (2010) Gefitinib versus cisplatin plus docetaxel in patients with non-small-cell lung cancer harbouring mutations of the epidermal growth factor receptor (WJTOG3405): an open label, randomised phase 3 trial. Lancet Oncol 11(2):121-128

13. Cameron D, Casey M, Press M, Lindquist D, Pienkowski T, Romieu CG, Chan S, Jagiello-Gruszfeld A, Kaufman B, Crown J, Chan A, Campone M, Viens P, Davidson N, Gorbounova V, Raats JI, Skarlos D, Newstat B, Roychowdhury D, Paoletti P, Oliva C, Rubin S, Stein S, Geyer CE (2008) A phase III randomized comparison of lapatinib plus capecitabine versus capecitabine alone in women with advanced breast cancer that has progressed on trastuzumab: updated efficacy and biomarker analyses. Breast Cancer Res Treat 112(3):533-543. doi:10.1007/s10549-007-9885-0

14. Geyer CE, Forster J, Lindquist D, Chan S, Romieu CG, Pienkowski T, Jagiello-Gruszfeld A, Crown J, Chan A, Kaufman B, Skarlos D, Campone M, Davidson N, Berger M, Oliva C, Rubin SD, Stein S, Cameron D (2006) Lapatinib plus capecitabine for HER2-positive advanced breast cancer. N Engl J Med 355(26):2733-2743. doi:10.1056/NEJMoa064320

15. Eskens FA, Mom CH, Planting AS, Gietema JA, Amelsberg A, Huisman H, van Doorn L, Burger H, Stopfer P, Verweij J, de Vries EG (2008) A phase I dose escalation study of BIBW 2992, an irreversible dual inhibitor of epidermal growth factor receptor 1 (EGFR) and 2 (HER2) tyrosine kinase in a 2-week on, 2-week off schedule in patients with advanced solid tumours. Br J Cancer 98 (1):80-85. doi:10.1038/sj.bjc.6604108

16. Li D, Ambrogio L, Shimamura T, Kubo S, Takahashi M, Chirieac LR, Padera RF, Shapiro GI, Baum A, Himmelsbach F, Rettig WJ, Meyerson M, Solca F, Greulich H, Wong KK (2008) BIBW2992, an irreversible EGFR/HER2 inhibitor highly effective in preclinical lung cancer models. Oncogene 27(34):4702-4711. doi:10.1038/onc.2008.109

17. Shimamura T, Gewulich H, Solca F, Wong K (2007) Efficacy of BIBW 2992, a potent irreversible inhibitor of EGFR and HER2 in human NSCLC xenografts and in a transgenic mouse lung-cancer model. J Thorac Oncol 2(8):S380

18. Solca F, Baum A, Guth B, Colbatzky F, Blech S, Amelsberg A, Himmelsbach F (2005) BIBW 2992, an irreversible dual EGFR/ 
HER2 receptor tyrosine kinase inhibitor for cancer therapy. Proceedings, AACR-NCI-EORTC International Conference on Molecular Targets and Cancer Therapeutics Philadelphia, PA 14-18 November 2005:118 (Abstract A244)

19. Marshall J, Lewis N, Amelsberg A, Briscoe J, Hwang J, Malik S, Cohen R (2005) A Phase I dose escalation study of BIBW 2992, an irreversible dual EGFR/HER2 receptor tyrosine kinase inhibitor, in a 3 week on 1 week off schedule in patients with advanced solid tumors. Proceedings, AACR-NCI-EORTC International Conference on Molecular Targets and Cancer Therapeutics:168(Abstract B161)

20. Lewis N, Marshall J, Amelsberg A, Cohen RB, Stopfer P, Hwang J, Malik S (2006) A phase I dose escalation study of BIBW 2992, an irreversible dual EGFR/HER2 receptor tyrosine kinase inhibitor, in a 3 week on 1 week off schedule in patients with advanced solid tumours. Journal of Clinical Oncology, 2006 ASCO Annual Meeting Proceedings Part I 24 (18S (June 20 supplement)): Abstract 3091

21. Yap TA, Vidal L, Adam J, Stephens P, Spicer J, Shaw H, Ang J, Temple G, Bell S, Shahidi M, Uttenreuther-Fischer M, Stopfer P, Futreal A, Calvert H, de Bono J, Plummer R (2010) Phase I trial of the irreversible EGFR and HER2 kinase inhibitor BIBW 2992 in patients with advanced solid tumors. J Clin Oncol 28(25):39653972

22. Trotti A, Colevas AD, Setser A, Rusch V, Jaques D, Budach V, Langer C, Murphy B, Cumberlin R, Coleman CN, Rubin P (2003) CTCAE v3.0: development of a comprehensive grading system for the adverse effects of cancer treatment. Semin Radiat Oncol 13 (3):176-181. doi:10.1016/S1053-4296(03)00031-6

23. Therasse P, Arbuck SG, Eisenhauer EA, Wanders J, Kaplan RS, Rubinstein L, Verweij J, Van Glabbeke M, van Oosterom AT, Christian MC, Gwyther SG (2000) New guidelines to evaluate the response to treatment in solid tumors. European Organization for Research and Treatment of Cancer, National Cancer Institute of the United States, National Cancer Institute of Canada. J Natl Cancer Inst 92(3):205-216

24. Engelman JA, Janne PA (2008) Mechanisms of acquired resistance to epidermal growth factor receptor tyrosine kinase inhibitors in non-small cell lung cancer. Clin Cancer Res 14(10):2895-2899. doi:10.1158/1078-0432.CCR-07-2248

25. Lin NU, Winer EP, Wheatley D, Carey LA, Houston S, Mendelson D, Munster P, Frakes L, Kelly S, Garcia AA, Cleator S, Uttenreuther-Fischer M, Jones H, Wind S, Vinisko R, Hickish T (2012) A phase II study of afatinib (BIBW 2992), an irreversible ErbB family blocker, in patients with HER2-positive metastatic breast cancer progressing after trastuzumab. Breast Cancer Res Treat 133(3):1057-1065. doi:10.1007/s10549-012-2003-y

26. Stopfer P, Schaefer HG, Amelsberg A, Huisman H, Eskens F, Gietema JA, Briscoe J, Lewis N, Cohen RB, Marshall J, Verweij J (2005) Pharmacokinetic results from two phase I dose escalation studies of once daily oral treatment with BIBW 2992, an irreversible dual EGFR/HER2 receptor tyrosine kinase inhibitor in patients with advanced tumours. Proceedings, AACR-NCI-EORTC International Conference on Molecular Targets and Cancer Therapeutics:171(Abstract B172)

27. Burris HA 3rd, Hurwitz HI, Dees EC, Dowlati A, Blackwell KL, O'Neil B, Marcom PK, Ellis MJ, Overmoyer B, Jones SF, Harris JL, Smith DA, Koch KM, Stead A, Mangum S, Spector NL (2005) Phase I safety, pharmacokinetics, and clinical activity study of lapatinib (GW572016), a reversible dual inhibitor of epidermal growth factor receptor tyrosine kinases, in heavily pretreated patients with metastatic carcinomas. J Clin Oncol 23(23):53055313

28. Hidalgo M, Bloedow D (2003) Pharmacokinetics and pharmacodynamics: maximizing the clinical potential of Erlotinib (Tarceva). Semin Oncol 30(3 Suppl 7):25-33

29. Arora A, Scholar EM (2005) Role of tyrosine kinase inhibitors in cancer therapy. J Pharmacol Exp Ther 315(3):971-979. doi:10.1124/jpet.105.084145

30. Grunwald V, Hidalgo M (2003) Developing inhibitors of the epidermal growth factor receptor for cancer treatment. J Natl Cancer Inst 95(12):851-867

31. Herbst RS, Maddox AM, Rothenberg ML, Small EJ, Rubin EH, Baselga J, Rojo F, Hong WK, Swaisland H, Averbuch SD, Ochs J, LoRusso PM (2002) Selective oral epidermal growth factor receptor tyrosine kinase inhibitor ZD1839 is generally well-tolerated and has activity in non-small-cell lung cancer and other solid tumors: results of a phase I trial. J Clin Oncol 20(18):3815-3825

32. Loriot Y, Perlemuter G, Malka D, Penault-Lorca F, Boige V, Deutsch E, Massard C, Armand JP, Soria JC (2008) Drug insight: gastrointestinal and hepatic adverse effects of molecular-targeted agents in cancer therapy. Nat Clin Pract Oncol 5(5):268-278. doi:10.1038/ncponc1087

33. Hidalgo M, Siu LL, Nemunaitis J, Rizzo J, Hammond LA, Takimoto C, Eckhardt SG, Tolcher A, Britten CD, Denis L, Ferrante K, Von Hoff DD, Silberman S, Rowinsky EK (2001) Phase I and pharmacologic study of OSI-774, an epidermal growth factor receptor tyrosine kinase inhibitor, in patients with advanced solid malignancies. J Clin Oncol 19(13):3267-3279

34. Ranson M, Hammond LA, Ferry D, Kris M, Tullo A, Murray PI, Miller V, Averbuch S, Ochs J, Morris C, Feyereislova A, Swaisland H, Rowinsky EK (2002) ZD1839, a selective oral epidermal growth factor receptor-tyrosine kinase inhibitor, is well tolerated and active in patients with solid, malignant tumors: results of a phase I trial. J Clin Oncol 20(9):2240-2250

35. Mom CH, Eskens FA, Gietema JA, Nooter K, De Jonge MJ, Amelsberg A, Huisman H, Stopfer P, De Vries EG, Verweij J (2006) Phase I study with BIBW 2992, an irreversible dual tyrosine kinase inhibitor of epidermal growth factor receptor 1 (EGFR) and 2 (HER2) in a 2-week on, 2-week off schedule. J Clin Oncol 24(18S):S3025

36. Lewis N, Marshall J, Amelsberg A, Cohen RB, Stopfer P, Hwang J, Malik S (2006) A phase I dose escalation study of BIBW 2992, an irreversible dual EGFR/HER2 receptor tyrosine kinase inhibitor, in a 3 week on 1 week off schedule in patients with advanced solid tumours. J Clin Oncol 24(18S):3091

37. Miller VA, Hirsh V, Cadranel J, Chen YM, Park K, Kim SW, Zhou C, Su WC, Wang M, Sun Y, Heo DS, Crino L, Tan EH, Chao TY, Shahidi M, Cong XJ, Lorence RM, Yang JC (2012) Afatinib versus placebo for patients with advanced, metastatic non-smallcell lung cancer after failure of erlotinib, gefitinib, or both, and one or two lines of chemotherapy (LUX-Lung 1): a phase $2 \mathrm{~b} / 3$ randomised trial. Lancet Oncol 13:528-538. doi:10.1016/S1470-2045 (12)70087-6

38. Yang JC-H, Schuler MH, Yamamoto N, O’Byrne KJ, Hirsh V, Mok T, Geater SL, Orlov S, V., Tsai C-M, Boyer MJ, Su W-S, Bennouna J, Kato TG, V., Lee, K. H., Shah, R. N. H., Massey, D., Lorence, R. L., Shahidi, M., Sequist, L.V. (2012) LUX-Lung 3: A randomized, open-label, phase III study of afatinib versus pemetrexed and cisplatin as first-line treatment for patients with advanced adenocarcinoma of the lung harboring EGFR-activating mutations. J Clin Oncol 30 (suppl; abstr LBA7500) 